\title{
DAYAH SANTRI IN ACEH: Early History and Recently Development
}

\author{
Zulfikar Ali Buto \& Hafifuddin \\ Institut Agama Islam Negeri Lhokseumawe \\ Jl. Banda Aceh-Medan, Buket Rata, Kota Lhokseumawe, 24352 \\ e-mail: zulfikar@iainlhokseumawe.ac.id, hafifuddin@iainlhokseumawe.ac.id
}

\begin{abstract}
This article examines the early history and recent developments of dayah santri in Aceh. This research is a combination of library research and field research. The approach used in this study is a historical approach. This study proposes that the modernization of the santri is divided into two phases. The first phase of pre-modernization, modernization of Acehnese santri only recognizes the world of students wearing a kupiah (cap), sarong, balee, reciting the Koran 10-25 years ago, returning to the village, establishing a small dayah, and so on. The second phase is the modernization phase, in this phase, the students experience modernization, in which students begin to openly follow formal education from Elementary School to Higher Education (S1-S3). Santri have started to participate and compete for strategic positions in the government of the DPRA Chairperson, Head of Service, Businessman, Head of the Religious Office, Chair of Local and National Parties, and students have expanded and continued their academic education to several European countries such as England, Spain, Germany, Turky to Latin America.
\end{abstract}

Keywords: santri, education, dayah, Aceh, modernization 


\section{Introduction}

The dynamics of the development of Islamic education institutions have historical treasures that are quite unique and interesting to discuss. Since Islam stepped in through the Prophet Muhammad, at that time the media used to carry out the spread and deepening of Islam was carried out at the house of a friend named Dâr Arqam and Kuttab. The use of the house of a friend named Arqam is an alternative to spreading Islam in Mecca secretly because the Prophet's movement is still very limited. With this condition, the Arqam's house was very possible to be used as a place for learning and introduction to Islam at that time. The followers (students) of this learning are the closest friends who are termed al-sâbiqûn al-awwalûn. Through this institution, many fighters and defenders of Islam were born as well as spreaders of Islam throughout the continent without exception Indonesia.

Starting the journey of Islamic education has actually grown and developed in line with the spread of Islam to the Arabian Peninsula. At the same time, Islamic education has a historical journey that scientifically has its own style and character in line with its continuous development. This historical incision was also continued after the struggle of the Prophet by his friends, the Mu'awiyah Dynasty, the Abbasid Dynasty, to the Asian Peninsula. According to the treasury of the social history of Islamic education, the development of Islam throughout the world is tucked into the history of the development of Islamic educational institutions which have contributed greatly to providing understanding and deepening as well as providing colors in the spread of Islam to other areas. This shows that the development of Islamic education institutions is also influenced by the character of the carrier (teachers) and students as developers who are conveyed in the course of Islamic education at that time. 
The historical incision of the arrival of Islam to the archipelago in the 1st century $\mathrm{H} . / 7 \mathrm{AD}$ is an early milestone in the development of Islamic education itself. Islamic education developed in line with the process of Islamization of society and the customs or culture of the archipelago. At that time, Islamic education was aimed at introducing and spreading Islam in the midst of Indonesian society through Persian, Arabic, and Gujarati traders, which were continued by the santri as the successor to the ulama. ${ }^{1}$ In the historical treasures of Islamic education, Sumatra was the first area to become a place for the spread of Islam. This was marked by the birth of the Islamic kingdom of Peurlak, Samudera Pasai, and the Kingdom of Aceh Darussalam. Because of the King's participation and support at that time, Islam became easily accepted and embraced by the community. Based on this condition, with the spread of Islam in Aceh by traders who stopped by and took the time to spread Islam, educational institutions were born in Aceh such as Dayah in Aceh, Surau in West Sumatra, and Islamic boarding schools in Java.

The establishment and development of the dayah in Aceh cannot be separated from the many Acehnese students who are learning to study in the Middle East. In addition, there were also many Arab, Persian, Egyptian, and Malabar scholars who came to Aceh, including the ancestors of Shaykh Abdurrauf alSingkilii ${ }^{2}$ or known as Syiah Kuala. ${ }^{3}$ These ulama developed dayah education in Aceh and used the term zawiya as the name of educational institutions such as those in the Middle East. ${ }^{4}$ Ideally, Aceh, which initiated islamization with the great scholars, should be able to grow and develop following past history. The background of the great ulama became the trigger and motivation to develop advanced Islam and spread throughout the Indonesian homeland. This is evident from the fact that through the Aceh and Sumatra regions, Islam continued to develop to the islands 
in the archipelago which were visited by scholars from Arab, Persian, and Gujarat including students from Aceh. Dayah has an important role in strengthening the Islamic intellectual tradition in the archipelago.

Given the development of the dayah in the past experienced tidal waves, now the ulama and santri who sit as dayah leaders must be able to arouse public interest in studying and studying at an educational institution called the dayah. The independence and uniqueness of the dayah should be a magnet to be able to thrive in the midst of competition in science and technology that is growing all over the world. The leaders (teachers) and dayah santri must now think in the midst of a wave of competition from other educational institutions that continue to modernize, reform, and syncretize. Teachers and students must wake up and see the development of a changing world. They must see development as a necessity, but not abandon the good values of old habits.

There have been many studies on dayah in Aceh, but so far there has been no study of the early history and recent developments of dayah santri in Aceh. Studies on dayah in general and dayah santri, in particular, have indeed been carried out by several researchers, for example Eka Srimulyani, ${ }^{5}$ Sri Suyanta, ${ }^{6}$ Anton Widyanto and Nur Fazillah, ${ }^{7}$ Fudhailul Barri, ${ }^{8}$ Nurhayati AR and Syahrizal, ${ }^{9}$ Syarifuddin Hashem, ${ }^{10}$ Nirzalin and Yogi F., ${ }^{11}$ and Nadlifah and Zainal Arifin. ${ }^{12}$ In this study, researchers focused on the early history of dayah santri in Aceh and its subsequent developments. This study is still relevant to be carried out considering the historical fact of Islamic education that dayah education institutions in Aceh have produced many great ulama from the past until today. Dayah students or alumni as well as the public need to know about the development of the santri profile which continues to develop quite rapidly. 


\section{Methodology}

This article is the result of research that combines library research and field research. The approach used in this research is a historical approach, especially the history of Islamic education which begins with determining the topic, looking for evidence through primary/secondary sources, assessing historical data, and then carrying out construction using simple, easy to understand language. ${ }^{13}$ Data collection techniques were carried out by observation, interviews, and documentation. The three of them are done simultaneously to obtain primary and secondary data during writing. The analysis was carried out by grouping the data, then formulating the data found, and finally the historical interpretation, historical expansion to the actual and systematic presentation, or presentation of history.

\section{Results and Discussion}

\section{Early History of Dayah Santri in Aceh}

Dayah is the Acehnese term for zawiyah which is taken from the zawiyah word. Literally, it is defined as a corner of the mosque which was used for teaching and preaching at the beginning of Islam at the time of the Prophet and his companions. This was explained by A. Hasjmy. The tongue of the Acehnese people calls zawiyah and then changes to the word dayah which is synonymous with the Islamic education institution that has developed in Aceh so far. A. Hasjmy stated that the goal of dayah educational institutions is to produce people who are ready to become sultans, ministers, cadres, or some other type of office activity in addition to being a propagator of religion and teachers in dayah institutions. ${ }^{14}$

The term santri is identified with the term pupil, but the term santri is more specific to institutions such as Islamic 
boarding school (pesantren)/dayah. In the realm of Islamic education, the term santri is identified with thâlib, fâqih, and tilmiz. During the presence of Imam al-Ghazâlî, the term tilmiz is closer to the designation of a student which means someone who asks for knowledge. Along with the social development of Indonesian society, the term santri is then synonymous with the word santri for those who study religion at the Islamic boarding school (pesantren) or dayah institutions. ${ }^{15}$

Based on the history of Islamic education in Indonesia, santri is an important element in an Islamic boarding school (pesantren) institution. However, it turns out that at the beginning of the dayah in Aceh, the word santri for students was more synonymous with the term student. In the case of Madrasah Nizhamiyah, students are synonymous with the terms thâlib, fâqih and tilmiz. For this reason, the word santri in the dayah refers to students who were present at the time of al-Ghazâlî for various reasons including as mentioned by Abd. Mukti who said the term tilmiz (pupil) comes from the root word talammaza which means "learn, can be on two sides, both religious and general." 16

Santri/students at dayah are usually divided into two groups. First, students go back and forth. Second, students who live in the dayah. Freelance students are usually recorded as students who come from the community around the dayah who ask $\mathrm{Abu}$ as the dayah leader to take part in learning back and forth from their respective homes without having to stay or live in the dayah. However, since the last few years, this provision has ceased to be enforced. Students who are registered as dayah santri either residing around the dayah or those who are far away, they are obliged to follow the dayah rules that have been set. All dayah students are required to live or reside in the hostel that has been prepared by the dayah. 
At the beginning of their growth, dayah santri in Aceh had a strong desire to deepen religious knowledge. They wanted to deepen Islamic knowledge further to some scholars from Arabia, Persia, and Gujarati. However, in historical records, little information has been obtained about who was a santri at the Cot Kala dayah as one of the oldest dayah in Aceh. What is clear is that some of the students who had studied there have succeeded in becoming scholars and at the same time establishing dayah in their respective areas of origin. For example, Dayah Seureuleu led by Teungku Shaykh Sirajuddin, Dayah Blang Pria led by Teungku Ja'kob, Dayah Batu Karang led by Teungku Ampon Tuan, Dayah Lam Keuneu'eun led by Teungku Shaykh Abdullah Kan'an, Dayah Tanoh Abee who led by Shaykh Nayan, son of Shaykh Fayrus and Dayah Tiro.

The Malay source also mentioned that the zawiya Cot Kala (Dayah Cot Kala) has produced several scholars spread across the Malay mainland including Maulana Ishak (Sunan Giri), Maulana Nur al-Din (Fatahillah), Sunan Gunung Jati, and Ampel Denta (Sunan Bonang). They are scholars who had studied at the Cot Kala dayah who were then sent to spread Islam to Java. Some students were sent to a number of areas in Aceh such as Mulana Abu Bakar to Malacca, Shaykh Ampon Tuan to Taming, and Shaykh Sirajuddin to Linge. ${ }^{17}$ Students who study at the Cot Kala dayah are not only students from the Aceh region, but also from outside Aceh, and then spread Islam in various parts of the archipelago.

Dayah is indeed much easier to develop because it gets more attention from the royal family. Santri who learns to gain knowledge also comes from noble families and ordinary people. This is in accordance with what was conveyed by Ishak Kasim in a dayah seminar with the theme Appreciation of Dayah as an Islamic Education Institution in Aceh which was carried 
out by the Committee of the VI Congress of the Board of the Dayah Inshafuddin Association in 2010. Based on the historical background of dayah development in Aceh in the past, dayah students usually come from aristocrats and peasant families who are very harmonious with the social environment. Between them, there is no difference in the economic level, and their social life is very close to one another. This condition has made the growth of dayah relatively easy in Aceh in the past. ${ }^{18}$

The reign of the Sultanate of Aceh Darussalam was a golden age in various fields including the development of the education sector. The reason is that the Aceh sultanate deliberately invited or brought in ulama outside Aceh to meet the needs of the kingdom and society, so the presence of ulama at that time was very much needed. Likewise, the development of the students, following the educational process with high enthusiasm coming from various parts of the archipelago. Their arrival becomes the foundation and hope for the spread of Islamic scholarship in the intellectual arena which is rooted in the values of the struggle for scientific wandering whenever and wherever they are. The number of knowledges travelers in Aceh was motivated by the golden age that was achieved by the kingdom of Aceh Darussalam at that time. These nomads from within and outside the country took turns fulfilling the desire to study various fields of study in Aceh at that time.

In addition, outside scholars who have been noted to have succeeded after obtaining their education in a dayah (Aceh) such as Shaykh Abdul Majid who once wrote a book of teachings originating from Manado also studied in Aceh during the Mahmud Syah sultanate (1760 M-1781M) then returned to Manado to develop Islam there. Likewise, with the scientific biography of a scholar from Patani (present-day Thailand), Dawud al-Fatani 
also from his biography recorded that he studied in Aceh in the era of the Aceh Sultanate. ${ }^{19}$

Some figures who have had education in Aceh, although there is no certainty and records that say they have studied in dayah. Among them is Teungku di Anjong whose real name is Sayyid Abu Bakr ibn Husain bin al-Faqih. He lived in the sultanates of Alaiddin Mahmud Syah (1760-1781) and Sultan Muhammad Syah (1781-1795). He founded a dayah at Anjong Pidie. Among his students were Tgk. Di Singkee and Sayyid Husain. Tgk. Di Singkee is a commander by the Sultan of Aceh, his son, King Bujang, was the founder of Trumon fort in 1830.

Then, Teungku Chik di Tiro has the full name Shaykh Muhammad Saman Tiro, born in $1251 \mathrm{H} / 1836$ AD. He is the son of Teungku Shaykh Abdullah bin Teungku Shaykh Ubaidillah Garot, while his mother is Sitti Aisyah. Before he was 15 years old, Muhammad Saman or Chik di Tiro studied at his father's/ mother's dayah at Garot Pidie. After he was 15 years old Muhammad Saman moved to Dayah Tiro under the tutelage of his uncle Teungku Chik Muhammad Amin Dayah Cut. From his education at Tiro, then he moved to Dayah Teungku Chik Yan Ie Leubeue, then successively moved to Dayah Teungku Chik Abdullah Meunasah Blang, then to Dayah Teungku Chik Tanjong Bungong and moved again to Dayah Teungku Chik Lam Krak in Aceh Besar. After receiving a lot of knowledge in various fields of knowledge, he received the blessing of his uncle to go to the Holy Land of Mecca to fulfil the fifth pillar of Islam, besides fulfilling his obligations, Muhammad Saman also took the time to deepen his knowledge and meet with Islamic leaders there. Not long in Makkah, Muhammad Saman returned to his homeland in conditions of war against the invaders. 
Then, Shaykh Daud Rumym, better known as Teugku Chiek in Leupeu, who together with Shaykh Abdur Rauf As-Singkily established the Manyang Leupeu Dayah Education Center in Banda Aceh. The results of his essays included the Risâlah Masâ'il Muhtadihi Ikhwân al-Mubtadi', which was written in Malay. This book contains complete lessons about the religion of Islam and is used throughout Southeast Asia. Until now it has been printed hundreds of times, used by all dayah in the archipelago.

There are still many Acehnese figures who have attended dayah education. The participation of the students in the war against the invaders resulted in the disconnection of the next generation of dayah who could be expected to rebuild the dayah after the sabi war ended. Upon their return to the dayah, the scholars tried to get up and rebuild the dayah they had left during the war. Here are some records of students who gained knowledge in the dayah during the struggle and post-independence in Aceh. ${ }^{20}$

Tengku H. Abdullah Hanafie was born in 1927 AD in Tanoh Mirah at the age of 62 died on Monday, November 20, $1989 \mathrm{AD}$ to be precise at 01:00 WIB. During his life when he was 11 years old, Teungku $\mathrm{H}$. Abdullah Hanafie started the Koran at the Dayah Blang Bladeh. After studying at Dayah Blang Bladeh, three years later he continued his education at Dayah Leupung (Aceh Besar), after two years in Leupung he moved to Dayah Lancok. Through his religious intellectual journey, the dayah he had visited the longest was Dayah Darussalm Labuhan Haji, South Aceh Regency.

Teungku Haji Abdullah Ujong Rimba was born in Gampong Ujong Rimba, Pidie Regency in $1900 \mathrm{AD}$. He is still a descendant of an uleebalang named Teungku Haji Hasyim Peusangan Aceh Utara. As in general, he obtained basic education in the family 
environment provided by his parents. Furthermore, Teungku Abdullah Ujong Rimba chose dayah as an institution to deepen his religious knowledge at that time. The first dayah he visited was Dayah Ie Leubeu and then to Dayah Lamsi, led by Teungku Panglima Polem Muhammad Daud in Aceh Besar District, to deepen hadith, interpretation, and jurisprudent.

Teungku Shaykh Abdul Hamid Samalanga was born in Jenib in $1902 \mathrm{AD}$, the second son of Tengku Haji Idris. Teungku Shaykh Abdul Hamid Samalanga is known as Hamid's father, his first education was started by his parents who were the leaders of Dayah Tanjongan Samalanga. Besides studying with his parents, he also studied at the Governement Inlandsche School Samalanga until graduation. He has active in various organizations. He also spearheaded the establishment of PUSA with Tengku Daud Beureueh, Teungku Abdurraman Meunasah Meucap, Teungku Hasballah Indrapuri, Teungku Abdul Wahab Seulimuem, and other scholars.

Teungku Abdul Djalil was born in Buloh Beureughang, North Aceh, when he was 6 years old, Teungku Abdul Djalil attended school in Dayah Bungkah then continued to Samalanga to study the science of tauhid. From there he continued his education to deepen his knowledge at Dayah Teungku Amin Djumpoh in Monggeudong Lhokseumawe around 1932 AD. Realizing his scientific line, he had also been a student of Teungku Hasan Krueng Kale in Aceh Besar District. ${ }^{21}$

Teungku Abdul Wahab Seulimuem was born in Gampong Buga, Seulimuem District, Aceh Besar in 1998 M. Teungku Abdul Wahab Seulimuem received his first education at the Government in land school in Seulimuem in 1908-1913 AD After that, he continued his education at the famous dayah, Dayah Jeurela in Suka Makmur sub-district, Aceh Besar from 1913 - 1925 AD, while studying at the dayah, he deepened a lot 
of Arabic, jurisprudence, Sufism, monotheism, history, hadith, and interpretation.

Teungku Abdurrahman Meunasah Meucap was born in Gampong Meunasah Meucap, Peusangan around 1897 AD when he was 12 years old. He went on a scientific journey at the initiative of his parents being escorted to the famous dayah in Samalanga Dayah Teungku Ulee Ceue. After studying for two years at Ulee Ceue, Teungku Abdurraman moved to Dayah Peudada, led by Cot Baden. After a year there then moved to Dayah Cot Meurak for 11 years, and then made scientific trips in several other dayahs such as Dayah Tanjong in Samalanga, Dayah Kuta Blang also in Samalanga, Dayah Garot in Pidie, and Dayah Lhokseumawe, but these daysah were not some are old.

Teungku Ahamad Hasballah Indrapuri was born on 3 June 1888 M./23 Ramadhan 1305 H. in Kampung Lam U Montasiek Aceh Besar. Teungku Ahmad Hasballah Indrapuri started his education from his parents by studying the Koran, and other religious issues. After learning the basics of religion from his parents, then Teungku Ahamad Hasballah Indrapuri studied in other dayah such as Dayah Piyeung, Dayah Samalanga, Dayah Titeu, and Dayah Lamjabat. ${ }^{22}$ Even though he studied in a state of war, Teungku Ahamad Hasballah Indrapuri has mastered Arabic, jurisprudence, tauhid, sufism, Islamic history, tafsir, and hadith.

Tuanku Musa Raja Keumala was born in Kuta Keumala Pidie to be precise in $1877 \mathrm{M} / 1$ Ramadhan $1297 \mathrm{H}$. Tuanku Raja Keumala is still a descendant of the Sultan of Aceh his father Toeankoe Hasjim Bangta Muda bin Tuanku Abdul Kadir and his mother named Cut Nyak Puan. He obtained Tuanku Raja Keumala's education in conditions of war so that his parents specially brought in a scholar of Arab descent Shaykh Dorab to teach him various sciences. 
Before the 20th century, an Acehnese scholar was born who had important icons and figures who revived and re-developed the dayah in Aceh. He is Tengku Shaykh Muhammad Wali Al Khalidy born in 1337 H/1917 AD in Gampong Blang Poroh, Labuhan Haji District, South Aceh. His parents were named Teungku Haji Salim (father) and his mother was Janat bint Keucik Nyak Ujud, his father came from the city of Baru, Batu Sangkar West Sumatra. Shaykh Haji Salim is the son of Teungku Malem Palito from Minangkabau who has been living in Aceh from generation to generation. ${ }^{23}$ Tengku Shaykh Muhammad Wali Al Khalidy has a small name with the nickname Nyak Wali, after being pious with the journey of knowledge, especially after completing the pilgrimage, his full name is Tengku Shaykh Muhammad Wali Al Khalidy, while his daily nickname is Teungku Shaykh Muda Wali or Teungku Muda Wali.

The following is the network of the students of the Darussalam Labuhan Haji South Aceh dayah school of Tengku Shaykh Muhammad Wali al-Khalidy who were scattered and subsequently established salafi dayah in Aceh. First, the first generation of Tengku Shaykh Muhammad Wali al-Khalidy students included Teungku Haji Adnan Mahmud, the founder of Dayah Ashabul Yamin in Bakongan, South Aceh, Teungku Ahmad Isa Peudada, Abu Jailani Musa Peudada Darus Sa'adah South Aceh, Teungku Abdullah Hanafi (Abu Tanoh Mirah Ahli al-Usuly), Syahabuddin Panteun (Abu Keumala), Teungku Jahi Ja'far Siddin Aceh Tenggara, Teungku Idrus Padang, Abu Labay Jati, Teungku Yusuf Alami South Aceh Bakongan, Teungku Marhaban bin Abu Krueng Kalee. Second, the Second Generation of Tengku Shaykh Muhammad Wali al-Khalidy students, namely Teungku Aziz Samalanga led by Dayah Ulumud Diniyah Islamiyah at Mesjid Raya Samalanga. Third, the third-generation student of Tengku Shaykh Muhammad Wali al-Khalidy, Abu Tumin Blang Bladeh, led by Dayah Babussalam 
Bireuen. Fourth, fourth generation students of Tengku Shaykh Muhammad Wali Al Khalidy such as Teungku Daud Zamzami (chairman of the Aceh Adad Council), Teungku Cot Klat (Aceh Besar), Teungku Muhammad PERTI (Lam Ateuk) Teungku Abdullah, and Teungku Jamaluddin (Teupin Punti) ${ }^{24}$

Through his students' descendants, Abu Aziz Samalanga, who developed as well as the forerunner of the growth of dayah in Aceh which has modernized to this day, including, such as Abu Ibrahim Lamno, Abu Kuta Krueng, Abu Kasim Tb, Tu in Jakarta, Abu Lhok Nibong (Abu Lhueng Angen), and Abu Ibrahim (Abu Panton Labu). While the lineage of students from Abu Tumin Blang Bladeh such as Teungku Ismail Ya'kob, Abu Mustafa Paloh Gadeng, Teungku Muhammad Ilyas, Teungku M. Diah Tanjong Mesjid, Teungku Nasruddin bin Ahmad, and Tengku Zainuddin Adamy. ${ }^{25}$

\section{Dayah Santri in Recently Development}

Currently, the dayah has undergone such modernization. Referring to the Indonesian dictionary, modernization comes from "modern" English which has been Latinized to be modern, which means the latest or current. ${ }^{26}$ The use of the term modernization in historical studies is defined as a transformation or total change from traditional or pre-modern common life in the sense of physical (institutional), work (technology), and paradigmatic changes in the direction of modern patterns that mark the progress of a nation, state and religion. In other words, modernization is a form of a paradigm shift in thinking and institutions which are usually directed changes based on careful planning. ${ }^{27}$ Likewise, with this discussion, the modernization of the santri in Aceh is a paradigm shift in thinking and institutions which 
are usually directed changes based on careful planning to achieve the common good.

Major reforms of the dayah system in Aceh from various components of the dayah. Dayah used to be considered antireform, anti-change, anti-modernization, and very closed to the times. Dayah today is like being born again with a face that is more accepting and fulfilling the times that are increasingly leaving humans. The analysis of this article focuses more on the modernization of dayah santri.

Currently, children of school age are not satisfied if they have never studied at a dayah or pesantren. Usually, every parent who has school-age children around the age of 13 always leaves their children with the father at least in a dayah type educational institution of the Rangkang type (a recitation center established by dayah alumni). So, from field observations, the majority of dayah alumni in various dayah in Aceh, after graduating from the dayah, especially the traditional dayah, continued their preaching by establishing a balee/ rangkang (religious study site) around their house. The balee/rangkang is used to teach children of the same age as early education and elementary school equivalent to the al-Qur'an Education Park (TPA).

The modernisation of dayah santri in Aceh is based on the aura and motivation of studying religion during the Dutch colonial period. The emergence of this motivation was closely related to the interests of the struggle against the Dutch nation. To confront and deal with the Dutch colonialism, religious statements had a considerable influence in arousing the spirit of jihad against the infidels. Religion is used as a stimulant for the value of jihad for the people of Aceh. The war against the Dutch was considered a jihad and the territory occupied by the Dutch was Dâr al- $\underline{H} a r b$. It was emphasized that if the Muslims died on the battlefield against the Dutch, then he would die in 
a martyr state and would go to heaven. More than that, the santri in the ranks of the ulama also issued a fatwa that it was permissible to forcibly take the property owned by the kafir al$\underline{h} a r b$, and the property was classified as ghanimah. This strategy of the spirit of jihad made the passion of the Acehnese struggle boil and the fighting spirit became even more unstoppable so that what was called holy war (Perang $S_{a b}$ ) occurred. It is in this condition that the growth of the dayah through the dayah santri and ulama continues to develop and progress until now.

In a religious context, Dayah tends to adhere to the Syâfi'iyah school of thought. Based on the books studied, the power to teach books written by Syâfi' iyah scholars. However, in recent years, the condition of people's religious practice has begun to become alarming with the emergence of various religious sects, sects, and ideologies. This concern continues to arise because many people join these sects which are closer to heresy and apostasy. The presence and development of these ideologies, sects, and streams in the midst of society have now opened the dayah community to play an active role and make people aware of the importance of monotheistic education for the power of syar' iyah beliefs. Thus, the dayah santri and ulama must open their eyes, expand the network and expand their role for the continued existence of the dayah in the midst of a society that is very thirsty for science and technology.

The educational function carried out by ulama and santri has been seen since Islam was introduced to the people of Aceh. One of the ways of spreading and introducing Islam to society at that time was through education. The zawiya educational institution is now known as dayah. The embodiment of this institution is the main fortress of defense of the Islamic share in Aceh. ${ }^{28}$ Through the intellectual network of dayah scholars and santri who are scattered in various parts of the region, both 
at home and abroad, it has provided different nuances to the development of the dayah. The dayah ulama and their intellectual networks that are increasingly accepted and occupy strategic positions in the government and the private sector provide fresh air to the growth of the dayah. The attention of dayah ulama and santri and dayah intellectual networks through alumni is now building the dayah community so that the paradigm of thinking continues to receive input from various regions. This proves that dayah ulama and santri have had the opportunity to continue their education at the tertiary level, both undergraduate (S1), postgraduate (S2), and doctoral (S3). Through these dayah scholars and santri, the dayah intellectual network is now developing and is able to provide enlightenment and contribution of thought to develop dayah in accordance with the developments and needs of today's society.

The modernization of the dayah in Aceh can be seen from the aspect of dayah santri as one of the most important parts of the dayah. The term santri dayah has existed since the time of Iskandar Muda until now where dayah students are called aneuk mit dayah and dayah students. This title does not necessarily appear in society. Based on the observations of researchers and interviews with community leaders, the above designation is given to someone who has resided and lived in the dayah. In addition, this nickname is usually given to someone who has studied in the dayah for decades and after returning to his hometown he founded a dayah. ${ }^{29}$

Currently, the dayah in Aceh is experiencing modernization. This can be seen from the results of a study of the two largest and oldest dayah in the Biureuen and Pide Jaya districts. First, dayah Mesjid Raya Ma'hadul Ulum Diniyah Islamiyah Mesjid Raya (MUDI Mesra) which is located in Mideun Jok Village, Settlements, Mesjid Raya, Samalanga District, Bireuen Regency, 
Aceh Province. This dayah was visited by the President of the Republic of Indonesia Mr. Joko Widodo and provided assistance for the building of ma'had 'aly which has the status of the AlAziziyah Samalanga Institute of the Islamic Religion (IAIA). Second, Dayah Darul Munawwarah Kuta Kreung, Pide Jaya Regency.

\section{Modernization of Dayah MUDI in Samalanga Grand Mosque}

The history of the establishment of Dayah MUDI Samalanga Grand Mosque, Bireuen District, Aceh along with the founding of the Grand Mosque of Samalanga with the groundbreaking of Sultan Iskandar Muda in 1607-1636 AD. The dayah institution or Ma'hadul Ulum Diniyah Islamiyah Grand Mosque (MUDI Mesra) is located in Mideun Jok Village, Grand Mosque Settlements, Samalanga District, Bireuen Regency, Aceh Province. At that time Dayah Mudi Samalanga Grand Mosque was led by a prominent cleric who was better known as Faqeh Abdul Ghani, but it is unfortunate that his biographical treasure was not recorded so that it cannot be surfaced at this time. Unfortunately, how long he has been in charge of this institution, and who his successor has been being unknown. ${ }^{30}$

Then after 1927, a historical record was found which narrated the journey of Dayah Mudi Samalanga Grand Mosque Bireuen Aceh leadership. Since 1927, Dayah Mudi Samalanga Grand Mosque Bireuen Aceh has been led by al-Mukarram Teungku Haji Syihabuddin bin Idris with a total of 100 students at that time and 50 santriwati. They were immediately cared for by 5 teungku as male teachers and 2 teungku inong.

After Teungku H. Syihabuddin bin Idris died in 1935 Dayah Mudi Samalanga Grand Mosque Bireuen Aceh was continued his leadership by his brother-in-law named Teungku Haji Hanafiah 
bin Abbas or better known as Teungku Abi. During his leadership, Dayah MUDI Samalanga Grand Mosque Bireuen Aceh cared for 150 santri and 50 santriwati. When he left for Makkah to carry out the pilgrimage, the leadership period was told to Teungku Muhammad Saleh for two years.

After Teungku Haji Hanafiah died in 1964 H, then Dayah Mudi Samalanga Bireuen Grand Mosque Aceh was led by a son-in-law named Teungku Haji Aziz bin Teungku Muhammad Saleh. Teungku Haji Abdul Aziz who was given the title abon ${ }^{31}$ and al-manthiqi. ${ }^{32}$ If traced in his scientific network, Teungku Abdul Aziz is a student of Abuya Muda Wali led by Dayah Darussalam Labuhan Haji South Aceh. Since his leadership, around 1959-1989 $\mathrm{H}$, the development of dayah has continued to monitor progress, this is indicated by the number of santri arriving more and more so that at that time santri lodging (dormitories) began to be built.

After Teungku Abdul Azis passed away in 1989, the reins of Dayah Mudi Samalanga Grand Mosque Bireuen Aceh were established through an agreement with alumni and the community, Abon's own son-in-law was appointed named Teungku Haji Hasanoel Bashry bin Haji Gadeng. The leadership of Teungku Haji Hasanoel Bashry bin Haji Gadeng or who is familiarly called Abon Samalanga is one of Teungku Abdul Aziz's son-inlaw and the senior santri Dayah Mudi Mesjid Raya Samalanga Bireuen Aceh at that time. ${ }^{33}$

Since its establishment until now Dayah Mudi Samalanga Grand Mosque Bireuen Aceh is a Salafi dayah that continues to maintain its traditional dayah system. Dayah MUDI Samalanga Grand Mosque Bireuen Aceh continues to teach the books that were taught in the previous dayah. However, since the MUDI Samalanga Grand Mosque Bireuen Aceh dayah was led by a prominent cleric Teungku Haji Hasanoel Bashry besides the 
dayah still maintaining his Islamic identity, the dayah tries to provide knowledge that can provide his needs according to the needs of the times.

Dayah MUDI Samalanga Grand Mosque has continued to develop from year to year. This shows that public interest in entering and studying religion continues to increase. Santri who studied at Dayah MUDI Samalanga Grand Mosque came from various regions both from inside and outside Aceh and there were also some people who came from abroad. The number of students currently studying at Dayah MUDI Samalanga Grand Mosque is 5,228 people, consist of 3,287 santriwan and 2,567 santriwati.

It is in line with what was conveyed by one of the teachers at the dayah who said that before 2003, anyone was allowed to enter the dayah and study, both young and old, even children were allowed to enter the dayah. However, considering the improvement and the education process in the dayah continues to be dense and increasing, then to enter this dayah must also be given conditions that will not be burdensome for the students to take part in the learning process in the dayah. However, there are no age restrictions for adult santri, anyone is allowed to enter and register at the dayah while the dayah capacity is still adequate. ${ }^{34}$ However, it seems that in order to improve the quality of dayah education, according to Abu himself, in the future, as a discourse on determining the age or age to enter and study at Dayah MUDI Samalanga Grand Mosque, it must be determined so that students do not lose from the aspect of age and can take advantage of their age for learning age. ${ }^{35}$

Along with its development, students who have deepened their knowledge at the MUDI dayah Samalanga Grand Mosque have made a lot of progress. The progress and development and modernization of dayah students are due to several things, 
including the students had opened up and continuing formal education both undergraduate (S1), undergraduate (S2), and doctoral (S3) at home and abroad, from the region. Asia to Europe. Furthermore, the students have started to dare to carve their works in various fields. The works of the creativity of the students are also proof that they are modernizing the needs and competencies of santri graduates, even though this knowledge is not specifically obtained, thanks to the paradigm of thinking and insight of the students they can design helicopters and toy planes and fly them. Even this creativity was exhibited at the Aceh education expo in 2013 and got the first runner up at this time.

The face of modernization of students at the Dayah Mudi Samalanga Grand Mosque continues to carry out various activities to increase their abilities according to the needs of the times. Since 2006, the students have established and developed an Arabic and English language center as has been done by other integrated dayah. By Tgk. Munawir, as the person in charge of the Language Institute Center at Dayah MUDI Samalanga Grand Mosque, said that students are not actually required to take part in the development of Arabic and English, but whoever wants to participate in these developments is required to live in a dormitory which is devoted to the development of Arabic and English. ${ }^{36}$ In addition, 2019 last June, Dayah also sent 25 students to study English in Pare in order to improve the quality of the language of the students, which is prepared to revive foreign languages in the dayah.

Language development activities as carried out by the Center for Language Development Institutions during dayah are the mastery and use of everyday language conversations. For this reason, the students are held twice a week muhadasah (conversation) which is monitored and guided directly by teungku dayah. The result of observations made several times that the majority of 
teachers who are responsible for language development centers are those who have and have completed education in the integrated and modern dayah.

Through the development of the competence of dayah students, it can be analyzed in-depth that the modernization of dayah students in various ways shows that dayah santri are now trying to breakthrough. This breakthrough can be seen from the opening of the paradigm of thinking so that they have dared to get out of the barriers that have been the rules created by the dayah social community. The face of modernization of dayah santri in their acceptance, which used to accept santri without certain social conditions, is now accepted in a structured manner and has standardization to be accepted and settled in the dayah. Based on the development of the dayah santri with all the advantages they gained in the dayah, now the santri are proven to be accepted and spread their wings to occupy strategic positions in society. The experience and knowledge they gained while studying in the dayah provided room for movement to occupy structural government positions such as Head of the Office of Religious Affairs (KUA), district heads, political party administrators, members of the people's representative council to become regents. The face of modernization of dayah santri through the IAIA al-Aziziyah Higher Education program, for example, with a bachelor's degree (S1), the students open up opportunities to expand their role in society upon their return from dayah.

To meet the needs of students not to go home and live in the midst of society, dayah has now taken steps including opening new educational units such as Kindergarten Schools, Madrasah Tsanawiyah Paket B, SMP Islam al-Aziziyah, SMP Islam Jami'ah al-Aziziyah, Vocational High School, and STAI Al-Aziziyah. In addition to the Dayah MUDI educational institution Samalanga 
Grand Mosque, building several work units as a forum for extra-curriculum development, established institutions to support creativity and experience in the world of work. First, the Pesantren Cooperative (Kopentren). This Kopentren has been born since (1982). Currently the cooperative is named Kopentren al-Barakah already has business units including Waserda (grocery) shop in the Dayah complex, savings and loan units, teacher canteens, and santri canteens, glassware shops in the market of Ulee Gle and the agriculture and plantation business unit. Second, Mitra Pesantren (Poskestren). This Poskestren is the first aid center to deal with the health problems of santri. This Poskestren is present in collaboration with the Samalanga Health Center. In the past 5 years, the students received health services immediately so they did not have to leave the dayah from professional medical personnel. Third, Mabna Lughah. Mabna Lughah is an institution where foreign languages (Arabic and English) are developed for the development of the language capacity of students. To support these activities, Mabna Lughah already has a language laboratory facility with modern facilities. Fourth, Lajnah Bahsul Masail. Lajnah Bahtsul Masa'il is a research and community service institution. Lajnah is managed directly by senior MUDI Dayah teachers. In addition to functioning as a place of study to discuss legal issues that occur in society, Lajnah Bahtsul Masa'il also functions as a laboratory to sharpen the understanding of students in the field of legal studies. Fifth, Carpentry and Workshop Training Center. This training center was built as a means to teach students about skills. Besides that, it is also a business unit that provides goods and services needed by the dayah community and society. Sixth, Alumni Rabitah. Fostering Rabitah Alumni of LPI MUDI Samalanga Grand Mosque intensively conducts coaching for its alumni so that the relationship between the main dayah and dayah alumni is effectively intertwined with both its vision and mission. The MUDI Samalanga Grand 
Mosque Institute has produced many alumni, some of whom continue their studies both at home and abroad, and some have worked in government agencies, are self-employed, and have worked by establishing dayah in their respective areas. Currently, the alumni fostered dayah branches have reached 423 dayah, and recitation centers spread across Aceh and outside Aceh. Thus, it means that the dayah has created graduates who are beneficial to the government and for society in developing a whole person. ${ }^{37}$

\section{Modernization of Dayah Dayah Darul Munawwarah}

Dayah Darul Munawwarah Kuta Krueng Pidie Jaya is a dayah that maintains its traditional system but has also opened up and accepted modernization according to the needs of the times. This was conveyed by one of the senior teachers at Dayah Darul Munawwarah Kuta Krueng Ulee Gle Pidie Jaya who said that: Basically, the dayah continues to implement its salafiyah system but by Abu Kuta Krueng (dayah leader) himself justifies santri or the teacher council to follow and continue school either at ma'had' aly or the like.

Dayah Darul Munawwarah Kuta Krueng Ulee Gle Pidie Jaya as a well-known dayah through its charismatic leadership and traditional or salafiyah learning system continues to strive for development.

Tracing the development of Dayah Darul Munawwarah Kuta Krueng from its establishment around 1964 with the leader of its first-generation being Tgk. H. Usman bin Ali who is familiarly called Abu Kuta Krueng. The history of Dayah Darul Munawwarah Kuta Krueng is the forerunner of dayah in general in Nanggroe Aceh Darussalam. Dayah Darul Munawarah Kuta Krueng originated from a langgar (surau) as a center for teaching 
Islam in the Kuta Krueng Pidie Jaya area approximately 1964 AD. In this langgar, several simple rooms were built for the students to stay. But from this simple violation, a dayah has grown which is now 50 years old.

As a dayah that continues to develop, Dayah Darul Munawwarah Kuta Krueng is trying to make improvements but does not abandon its traditionalism principles. One of the developments that continue to be carried out is the development of the Dayah Darul Munawwarah Kuta Krueng curriculum which is almost the same as the Dayah MUDI Samalanga big mosque. This is because Abu Alone was a MUDI Dayah graduate during the leadership of Abu Aziz Samalanga. The dayah curriculum has been recorded to have 3 levels. Namely Tahjizi (matriculation) for 1 year, the level of 'Aliyah for 3 years, and ma'had 'aly for 4 years.

It is clear that there is a modernization of Dayah's santri Darul Munawwarah Kuta Krueng Pidie Jaya. The ma'had 'aly program has been implemented for the last two years, although it has not yet produced graduates, with the enthusiasm and support of Abu as dayah leader, now the program has two levels with a total of 96 students. They are dayah teachers who have high motivation to finish college and can develop it after finishing in the dayah.

Other programs in various dayah activities carried out to support the curriculum above the dayah also prepare extracurricular for the students. The extras of the curriculum at the Darul Munawwarah dayah to support the dayah curriculum include the ability to jahid, computer skills, and workshop skills. Although not all students are required to follow it, the enthusiasm of the santri, especially the senior students, has a high motivation to do it. This is seen as very positive; besides they are given a curriculum for deepening religious knowledge, 
they are also provided with life skills to prepare them after graduating from dayah.

Based on observations, the interview document study of the face of the modernization of Dayah Darul Munawwarah Kuta Kreung students has begun to open up. Dayah Darul Munawwarah Kuta Krueng Pidie Jaya is a dayah that maintains its traditional system but has also opened up and accepted modernization according to the needs of the times. This was conveyed by one of the senior teachers (alumni) at Dayah Darul Munawwarah Kuta Krueng Ulee Gle Pidie Jaya who said that basically, dayah continue to implement the salafiyah system. However, Abu Kuta Krueng (dayah leader) justified the santri or the board of teachers to attend and continue their studies either at ma 'had 'aly or the like. ${ }^{38}$

Dayah Darul Munawwarah Kuta Krueng Ulee Gle Pidie Jaya as a well-known dayah through its charismatic leadership and traditional or salafiyah learning system continues to strive for development. The Dayah Darul Munawwarah Kuta Krueng students who relatively still had a paradigm of thinking as a traditional dayah. His activities still revolve around the deepening of the yellow book alone. However, dayah is now preparing its students to be able to master computers even though only a few students are interested in following and studying them. The face of modernization of the santri can only be seen in the motivation of the students to take part in the dayah manyang program which has been going on for the fifth year and now has the 7th generation. The program was followed by students who had completed mu'adalah classes. The mu'adalah class is the class for the teungku rangkang who has sat in grade 7 dayah.

This is in accordance with what was conveyed by Tgk. Akhiyar, one of the teachers and students of the ma'had 'aly 
program, said that the dayah santri who took part in the ma'had 'aly program were those who had finished the mu'adalah class, namely having completed grade 7 Dayah Darul Munawwarah Kuta Krueng Ulee Gle. ${ }^{39}$ Some of the other students who took part in the ma'had 'aly program were Tgk. Maula Zikri (born in Pidie, 11 August 1988) and Dhiauddin (born in Meulaboh, 19 January 1992). The existence of dayah manyang at Dayah Kuta Kreueng Pidie Jaya is the result of collaboration with the Aceh government which provides opportunities for dayah who are ready to run the program. The implementation is also adjusted to the ability of the dayah concerned. For the Darul Munawwarah Kuta Krueng Dayah Manyang program, which has a religious jurisprudent concentration, it is hoped that later intellectuals who are intellectual and have an important role in religious institutions such as the Ulama Consultative Council (MPU), employees of the Office of Religious Affairs, party heads, party administrators, contractors, and entrepreneurs.

Meanwhile, there is no doubt about having an active role in various religious fields. The alumni and senior dayah santri continue to develop their scientific competencies. Most of them have succeeded in devoting themselves to society, both by establishing dayah cut and dayah chik. For senior dayah students who are still listed as santri and teungku rangkang, they devote themselves to the community around the dayah by filling out the scheduled recitations every week. Through this service, it is hoped that they will be able to deepen and broaden life experiences before returning to their respective hometowns.

It is clear that Dayah Darul Munawwarah Kuta Krueng Pidie Jaya is now trying to make improvements in various existing aspects. Even though it continues to implement the dayah salafiyah system, through its vision it can be seen that the dayah also has an effort to make its students independent 
in various ways. In addition, dayah also through its mission seeks to educate its students to foster the piety of students through faith, knowledge, and good deeds. Through these three things, it will really be difficult to fulfill if not accompanied by the knowledge that is in accordance with the needs of society and the demands of the times and today's realities. The students will find it difficult to adapt to any conditions if the dayah graduates also do not master the development of society and the developments of this era which researchers call the face of the modernization of dayah students in Aceh.

\section{Conclusion}

This study proposes two conclusions, the modernization of dayah santri in Aceh is divided into two facets. The first phase of pre-modernization, modernization of Acehnese santri only recognizes the world of students wearing a kupiah (cap), sarong, balee, reciting the Koran 10-25 years ago, returning to the village, establishing a small dayah, and so on. The second phase is the modernization phase, in this phase, the students experience modernization, in which students begin to openly follow formal education from elementary to tertiary education (S1-S3). Santri have started to follow and compete for strategic positions in the government of the DPRA Chairperson, Head of Service, Businessman, Head of the Religious Office, Chairman of Local and National Parties, and students have expanded and continued their academic education to several European countries such as England, Spain, Germany, Turkey and Latin America.

\section{References}

A., Sabri. Biografi Ulama-ulama Abad XX. Banda Aceh: Dinas Pendidikan NAD, 2003. 
Abbas, Sirajuddin. Sejarah dan Keagungan Mazhab Syafïi. Jakarta: Pustaka Pelajar, 2004.

Abu MUDI (Hasanoel Bashry), the leader of Dayah MUDI Mesjid Raya Samalanga, interview in Samalanga, 23 Juni 2018.

Ali Buto, Zulfikar. Modernisasi Dayah di Aceh. Banda Aceh: Madani Publisher, 2017.

Ali, Mukti. An Introduction to the Government of Acheh's Sultanate. Yogyakarta: Nida, 1970.

Amiruddin, M. Hasbi. Perjuangan Ulama Aceh di Tengah Konflik. Yogyakarta: Ceninnets Press, 2004.

Amiruddin, M. Hasbi. Ulama Dayah Pengawal Agama Masyarakat Aceh. Lhokseumawe: Nadiya Pondation, 2007.

Amiruddin, M. Hasbi. Jam'iyatu al-Diniyah: Pemrakarsa Lahir Madrasah di Aceh. Banda Aceh: P3KI IAIN Ar-Raniry Banda Aceh, 2011.

Amiruddin, M. Hasbi. Ulama dan Politik Menyongsong Aceh Baru. Banda Aceh: LSMA and STAIN Malikussaleh, 2011.

AR., Nuryahati, and Syahrizal. "Hubungan Kecerdasan Intelektual Dengan Prestasi Belajar Santri Dayah Terpadu Almadinatuddiniyah Syamsuddhuha Cot Murong Aceh Utara," in Edukasi, Vol. 14, No. 2, 2017.

Barri, Fudhailul. "Manajemen Waktu Santri di Dayah Tahfidz Ulumul Qur'an Pagar Air Banda Aceh," in Jurnal Ilmiah Didaktika, Vol. 17, No. 1, 2016.

Dhuhri, Saifuddin. Dayah Menapaki Jejak Pendidikan Warisan Endatu Aceh. Banda Aceh: Lhee Sagoe Press, 2014.

Hashem, Syarifuddin. "Keefektifan Pembelajaran Mufradat Untuk Meningkatkan Kemahiran Berbicara Bahasa Arab Santri Dayah di Kota Banda Aceh,” in Lisanuna, Vol. 5, No. 1, 2016. 
Hasjmy, A. Ulama Aceh Mujahid Pejuang Kemerdekaan dan Pembangunan Tamadun Bangsa. Banda Aceh: Bulan Bintang, 1997.

Hasjmy, A. Sejarah Kebudayaan Islam di Indonesia. Jakarta: Bulan Bintang, 1990.

Kasim, Ishak. "Apresiasi Terhadap Masa Depan Dayah sebagai Suatu Lembaga Pendidikan dan Penyiaran Agama Islam," in Apresiasi Dayah sebagai Lembaga Pendidikan Islam di Aceh. Banda Aceh: Pengurus Besar Persatuan Dayah Inshafuddin, 2010.

Mukti, Abd. Konstruksi Pendidikan Islam: Belajar dari Kejayaan Madrasah Nizhamiyah Dinasti Saljuq. Bandung: Citapusaka Media, 2007.

Nadlifah, et al. "Charismatic-Visionary Leadership of Teungku in Developing the Role of Dayah Mudi Mesra Samalanga, Bireun, Aceh,” in Cendekia: Jurnal Kependidikan dan Kemasyarakatan, Vol. 18, No. 1, 2020.

Nirzalin, and Yogi F. "Teungku Dayah Agency and Religious Social Capital on Drug Eradication in Aceh, Indonesia," in Jurnal Ilmu Sosial dan Ilmu Politik, Vol. 23, No. 3, 2020.

Siddiq, Jafar. "Modernisasi Surau di Minangkabau." Paper presented at the Lecture for the Doctoral Program of IAIN North Sumatra, Medan, April 13, 2012.

Sri Hartatik, Endah. Metode Penelitian Sejarah. Yogyakarta: Pustaka Utama, 2018.

Srimulyani, Eka. "Islamic Schooling in Aceh: Change, Reform, and Local Context," in Studia Islamika, Vol. 20, No. 3, 2013.

Suharto and Tata Iryanto. Kamus Bahasa Indonesia. Surabaya: Indah Surabaya, 1996.

Suyanta, Sri. “Idealitas Kemandirian Dayah,” in Jurnal Ilmiah Islam Futura, Vol. 11, No. 2, 2012. 
Syukri Yeoh Abdullah, Mohd. Zawiyah Dalam Lipatan Sejarah \& Kebudayaan Alam Melayu. Malaysia: Institut Alam dan Tamaddun Melayu Universitas Kebangsaan Malaysia, 2011.

Tgk. Akhiyar, teacher of Dayah Darul Munawwarah Kuta Krueng Ulee Gle, interview in Ulee Gle, Oktober 24, 2018.

Tgk. Husni, alumni of Dayah MUDI Mesra Samalanga, interview in Aceh, Agustus 29, 2014.

Tgk. Muhammad, Teungku of Dayah Darul Munawwarah Kuta Krueng Ulee Gle Pidie Jaya, interview in Pidie Jaya, November 24, 2014.

Tgk. Mukhlisuddin, teacher of Dayah MUDI Kesjid Raya Samalang, interveiw in Samalanga, May 23, 2018.

Tgk. Munawir, teacher of Dayah MUDI Mesjid Raya Samalanga, interview in Samalanga, June 2, 2014.

Thahiry, Muslim, et al. Wacana Pemikiran Santri Dayah. Banda Aceh: Wacana Press, 2007.

Tim Penulis Dayah MUDI Mesra. Profil Ringkas Dayah MUDI Mesra Samalanga. Bireuen: n.p., 2010.

Tim Penulis. Ulama Aceh Dalam Melahirkan Human Resource di Aceh. Banda Aceh: Yayasan Aceh Mandiri, 2010.

Widyanto, Anton, and Nur Fazillah. "Peran Kepemimpinan Pimpinan Dayah dalam Membentuk Akhlak Santri di Dayah Raudhatul Qur'an Tungkob," in Dayah, Vol. 2, No. 2, 2019. 


\section{Endnotes:}

${ }^{1}$ A. Hasjmy, Sejarah Kebudayaan Islam di Indonesia (Jakarta: Bulan Bintang, 1990), p. 57.

${ }^{2}$ See, M. Hasbi Amiruddin, Ulama Dayah Pengawal Agama Masyarakat Aceh (Lhokseumawe: Nadiya Pondation, 2007), p. 11; Azumardi Azra, Jaringan Ulama Timur Tengah dan Kepulauan Nusantara Abad XVII dan XVIII (Bandung: Prenada, 2006), p. 252.

${ }^{3}$ Mukti Ali, An Introduction to the Government of Acheh's Sultanate (Yogyakarta: Nida, 1970), p. 8.

${ }^{4}$ Muslim Thahiry, et al. Wacana Pemikiran Santri Dayah (BRR Nad-Nias, PKPM Aceh: Wacana Press, 2007), p. 152.

${ }^{5}$ Eka Srimulyani, "Islamic Schooling in Aceh: Change, Reform, and Local Context," in Studia Islamika, Vol. 20, No. 3, 2013.

${ }^{6}$ Sri Suyanta, "Idealitas Kemandirian Dayah," in Jurnal Ilmiah Islam Futura, Vol. 11, No. 2, 2012.

${ }^{7}$ Anton Widyanto and Nur Fazillah, "Peran Kepemimpinan Pimpinan Dayah dalam Membentuk Akhlak Santri di Dayah Raudhatul Qur'an Tungkob," in Dayah, Vol. 2, No. 2, 2019.

${ }^{8}$ Fudhailul Barri, "Manajemen Waktu Santri di Dayah Tahfidz Ulumul Qur'an Pagar Air Banda Aceh,” in Jurnal Ilmiah Didaktika, Vol. 17, No. 1, 2016.

${ }_{9}$ Nuryahati AR and Syahrizal, "Hubungan Kecerdasan Intelektual Dengan Prestasi Belajar Santri Dayah Terpadu Almadinatuddiniyah Syamsuddhuha Cot Murong Aceh Utara," in Edukasi, Vol. 14, No. 2, 2017.

${ }^{10}$ Syarifuddin Hashem, "Keefektifan Pembelajaran Mufradat Untuk Meningkatkan Kemahiran Berbicara Bahasa Arab Santri Dayah di Kota Banda Aceh,” in Lisanuna, Vol. 5, No. 1, 2016.

${ }^{11}$ Nirzalin and Yogi F., "Teungku Dayah Agency and Religious Social Capital on Drug Eradication in Aceh, Indonesia," in Jurnal Ilmu Sosial dan Ilmu Politik, Vol. 23, No. 3, p. 210-222.

${ }^{12}$ Nadlifah, et al. "Charismatic-Visionary Leadership of Teungku in Developing The Role of Dayah Mudi Mesra Samalanga, Bireun, Aceh," in Cendekia: Jurnal Kependidikan Dan Kemasyarakatan, Vol. 18, No. 1, p. 139-154.

${ }^{13}$ Endah Sri Hartatik, Metode Penelitian Sejarah (Yogyakarta: Pustaka Utama, 2018), p. 11-12.

${ }^{14}$ Saifuddin Dhuhri, Dayah Menapaki Jejak Pendidikan Warisan Endatu Aceh (Banda Aceh: Lhee Sagoe Press, 2014), p. 21.

${ }^{15}$ Zulfikar Ali Buto, Modernisasi Dayah di Aceh (Banda Aceh: Madani Fublisher, 2017), p. 44

${ }^{16}$ Abd. Mukti, Konstruksi Pendidikan Islam: Belajar dari Kejayaan Madrasah Nizhamiyah Dinasti Saljuq (Bandung: Citapusaka Media, 2007), p. 212. 
${ }^{17}$ Mohd. Syukri Yeoh Abdullah, Zawiyah Dalam Lipatan Sejarah \& Kebudayaan Alam Melayu (Malaysia: Institut Alam dan Tamaddun Melayu Universitas Kebangsaan Malaysia, 2011), p. 6.

${ }^{18}$ Ishak Kasim, "Apresiasi Terhadap Masa Depan Dayah sebagai Suatu Lembaga Pendidikan dan Penyiaran Agama Islam," in Apresiasi Dayah Sebagai Lembaga Pendidikan Islam di Aceh (Banda Aceh: Pengurus Besar Persatuan Dayah Inshafuddin, 2010), p. 235.

${ }^{19}$ M. Hasbi Amiruddin, Perjuangan Ulama Aceh di Tengah Konflik (Yogyakarta: Ceninnets Press, 2004) p. 34.

${ }^{20}$ M. Hasbi Amiruddin, Jam'iyatu al-Diniyah: Pemrakarsa Lahir Madrasah di Aceh (Banda Aceh: P3KI IAIN Ar-Raniry Banda Aceh, 2011), p. 29.

${ }^{21}$ Sabri A., Biografi Ulama-ulama Abad XX (Nanggroe Aceh Darussalam: Dinas Pendidikan NAD, 2003), p. 21.

${ }^{22}$ Ibid., p. 37.

${ }^{23}$ A. Hasjmy, Ulama Aceh Mujahid Pejuang Kemerdekaan dan Pembangunan Tamadun Bangsa (Banda Aceh: Bulan Bintang, 1997), p. 203.

${ }^{24}$ Sirajuddin Abbas, Sejarah dan Keagungan Mazhab Syafíi (Jakarta: Pustaka Pelajar, 2004), p. 262-263.

${ }^{25}$ Ibid., p. 52.

${ }^{26}$ Suharto and Tata Iryanto, Kamus Bahasa Indonesia (Surabaya: Indah Surabaya, 1996), p. 170.

${ }^{27}$ Jafar Siddiq, "Modernisasi Surau di Minangkabau" (Paper presented at the Lecture for the Doctoral Program of IAIN North Sumatra, Medan, April 13, 2012).

${ }^{28}$ M. Hasbi Amiruddin, Ulama dan Politik Menyongsong Aceh Baru (Banda Aceh: LSMA and STAIN Malikussaleh, 2011), p. 43.

${ }^{29}$ Tgk. Husni, alumni of Dayah MUDI Mesra Samalanga, interview in Samalanga, Agustust 29, 2014.

${ }^{30}$ Tim Penulis Dayah MUDI Mesra, Profil Ringkas Dayah MUDI Mesra Samalanga (Bireuen: n.p., 2010), p. 3.

${ }^{31} \mathrm{Abon}$ or $\mathrm{Abu}$ is an honorary title given by the people of Aceh to someone who has the depth of Islamic knowledge and is charismatic in the midst of society. See, Tim Penulis, Ulama Aceh Dalam Melahirkan Human Resource di Aceh (Banda Aceh: Yayasan Aceh Mandiri, 2010), p. 5.

${ }^{32}$ Manthiqi is a title that is given by a teacher or society to someone who has expertise in the field of mantiq science.

${ }^{33}$ Tim Penulis Dayah MUDI Mesra, Profil Ringkas, p. 3-5.

${ }^{34}$ Tgk. Mukhlisuddin, teacher of Dayah MUDI Kesjid Raya Samalang, interview in Samalanga, May 23, 2018.

${ }^{35}$ Abu MUDI (Hasanoel Bashry), the leader of Dayah MUDI Mesjid Raya Samalanga, interview in Samalanga, June 23, 2018. 
${ }^{36}$ Tgk. Munawir, teacher of Dayah MUDI Mesjid Raya Samalanga, interview in Samalanga, June 2, 2014.

${ }^{37}$ Tim Penulis Dayah MUDI Mesra, Profil Ringkas, p. 31-32.

${ }^{38}$ Tgk. Muhammad, Teungku of Dayah Darul Munawwarah Kuta Krueng Ulee Gle Pidie Jaya, interview in Pidie Jaya, November 24, 2018.

${ }^{39}$ Tgk. Akhiyar, teacher of Dayah Darul Munawwarah Kuta Krueng Ulee Gle, interview in Ulee Gle, October 24, 2018. 